\title{
Politics, Poetry, People: an Overview of Contemporary Poetry Trends in the British Literary Landscape
}

\author{
Evgeniia Zimina \\ Kostroma State University \\ Mariana Sargsyan \\ Yerevan State University
}

\begin{abstract}
The article deals primarily with the poetic discourse surrounding the 2014 Scottish Independence Referendum and the post-referendum developments in the UK. The political processes of the recent years have been unprecedented in terms of the public resonance, which was by and large due to the active involvement of the social media. By examining the language and rhetoric strategies used in poems we become aware of the message behind them, of the political ideologies they are based on and of the means employed to address the public. It is argued that poetry, whether traditional or digital, sentimental or furious, played and still continues to play a significant role in shaping debate over mega political processes in the UK and in affecting people's opinion.
\end{abstract}

Key words: 2014 Scottish Independence Referendum, Brexit, nationalism, politics, poetry, social media, amateur authors.

\section{Like Scotland, slightly synthetic and in a state of indecision.} (Stewart Sanderson, Aiblins, 2016)

\section{Introduction}

On 18 September 2014, the people of Scotland were asked whether "Scotland should be an Independent country?" In fact a question which could receive its final answer after many decades of illusions of freedom. The whole 
country was divided into "YES" and "NO" /Better Together/ sides. Scottish Independence Referendum involved the highest ever turnout with 84.6 percent of voters. In response to the question 55.3 percent of voters answered "NO", leaving the YES voters disappointed and grieving for the lost chance, but at the same time with the realization of the fact that Scotland will never be the same.

The Scottish referendum (or Indyref) might have become a case of local voting, which would have been soon forgotten. It would have remained a curious historic fact, had it not been for another referendum: the referendum aimed to decide whether the UK should leave the European Union. Scotland, outraged by the outcome, is now considering the second Indyref as it has always manifested its commitment to European values. While saying YES in 2014 Scotland could not expect that it would stay with England but out of the EU.

In the frameworks of the present research our interest will be focused not as much on the outcome of the major political process from the socio-economic and political aspects, rather we will concentrate on the emotional aspect of the pre- and post- Referendum atmosphere and how that atmosphere was reflected in poetry.

Scottish literary landscape has always been noted for being rather politicized, but in the force of the events of the recent years that landscape, including Scottish literature, poetry and theatre, came to be extremely politicized, which demonstrates the growing politicization of the society and the postponed triumph of Scottish nationalism. Even now, four years after the Referendum, the question "What now?" continues to hover around boundaries and borders of Scotland, at the same time serving as catalyst for creativity.

It is not by chance that on 23 September 2015, one year after the Referendum the National Library of Scotland hosted a publicly engaged symposium on 'Poetic Politics: Culture and the 2014 Scottish Independence Referendum, One Year On', the aim of which was to stimulate interinstitutional dialogue on various aspects of Referendum and related issues. In her opening address Cabinet Secretary for Culture underlined the important role of the artists and performers in "shaping discussion about what the future of Scotland might look like, using their creativity to explore the big questions thrown up by 
the Referendum, challenging us to reflect about our past, present and most importantly our future' (<https://www.youtube.com/watch?v=rjoXXEc7qo8 $\geq$ ).

\section{Poets Shaping Debate on the Scottish Independence Referendum}

The ideas of Scottish independence were manifested through poetry much earlier than the $21^{\text {st }}$ century. As early as in the 1930s Hugh McDiarmid in his poem The Drunk Man Looks at the Thistle and a number of shorter verses expressed thoughts of freedom from England. England, in his opinion, was the major factor hindering Scottish progress. However, these ideas, expressed in an undoubtedly radical way, were treated cautiously even by ardent supporters of Scottish independence.

It was in the 1980s when Edwin Morgan published a collection of poems, Sonnets from Scotland, as a response to the botched Devolution Referendum of 1979, when Scotland voted for its own Parliament only to be told by Westminster that their majority was not enough. The idea of Scotland as a parliamentary republic seized Morgan's imagination. The republican government could only be possible if Scotland became independent from the UK, as the UK is a monarchy. The poem The Coin describes time travellers who arrive in Scotland in the very far future and find an ancient coin with the Latin inscription Respublica Scotorum (Wallace 2002). However, time-travellers come to Scotland only to find wasteland and swamps, obscured by the fog. It may mean that when the poem was written, the poet was not sure whether independence and the republic would make Scotland a prosperous country.

Scotland re-opened its Parliament only in 1999 as a result of the repeat referendum, and in 2004 Parliament moved into a new building, constructed specially for the purpose. It may seem to be an insignificant event, but it has a deep symbolic meaning. Edwin Morgan wrote a poem For the Opening of the Scottish Parliament, 9 October 2004, dedicated to the new building, to underline the new values. The poet compares the two types of buildings: old constructions associated with the Empire, and the new, built of local materials, airy and sunny. The description of the interior is followed by the collective image of the politicians who are going to work in this new building: 
What do the people want of the place? They want it to be filled with thinking

persons as open and adventurous as its architecture.

$A$ nest of fearties is what they do not want.

A symposium of procrastinators is what they do not want.

A phalanx of forelock-tuggers is what they do not want.

And perhaps above all the droopy mantra of 'it wizny me' is what they do not want.

Dear friends, dear lawgivers, dear parliamentarians, you are picking up a thread of

pride and self-esteem that has been almost but not quite, oh no not quite,

not ever broken or forgotten. (Morgan 2004)

It is extremely unusual to address politicians as "dear friends". Yet, it is a clear sign of belief in grass-root democracy. The poet also says: Forget, or don't forget, the past. This reference to the frosty relations between England and Scotland does not imply any belligerence towards England. However, it is a hint that the struggle for independence is only beginning. The end of the poem is written in the form of advice to politicians from common people. The poet makes it clear that the fight should be won not with weapons, but with thinking minds.

Many poems emerged during 2013-2014 and after, many of them random poems, written on the spot and not even published anywhere. However, the period was prolific for a number of renowned poets for whom poetry was a means of voicing the troubled minds and the uncertainty that awaited the country. Among them was Edinburgh Makar Christine De Luca whose poem The Morning After (2014) aimed to encourage the people to come back to normal life no matter what the result. As evident from the title, De Luca's major concentration is on 19 September 2014, the day after the Referendum, which 
was to be a pivotal day for all the sides. The "day after" is imagined as the time of a new start, with the full understanding of the fact that there should be no dividing lines between "Yes" and "No" sides because all of them are one nation and are destined to continue to live together.

Was it about the powers we gain or how we use them? We aim for more equality; and for tomorrow to be more peaceful than today; for fairness, opportunity, the common weal; a hand stretched out in ready hospitality.

The question (Was it about the powers we gain or how we use them?) posed by De Luca is whether the Referendum was all about the power to be gained, or how to use this power for the benefit of all, for the final goal for all the sides was the equality of opportunities and stability for all. This is a challenging question for those voters who believed that the independence was not an end in itself, while the "Yes" supporters believed that prosperity and fairness are at the heart of the case for independence. The poem argues controversial policies conducted by Westminster, which would not have been allowed if Scotland was in charge of all its affairs. The Referendum day is seen by De Luca as a balance sheet where the "folly and wisdom" and "risk and fearlessness"were to confront for much was at stake.

What is most challenging in this poem is that De Luca avoids adhering to any side, instead she takes a different turn by making an appeal to unite the efforts of both sides for the sake of those "unseen things" that unite the people of Scotland.

It's those unseen things that bind us, not flag or battle-weary turf or tartan.

There are dragons to slay whatever happens:

poverty, false pride, snobbery, sectarian

schisms still hovering. But there's

nothing broken that's not repairable. 
We're a citizenry of bonnie fighters,

a gathered folk; a culture that imparts,

inspires, demands a rare devotion,

no back-tracking; that each should work

and play our several parts to bring about

the best in Scotland, an open heart.

The cultural aspect that unites the Scots is of crucial importance for the preservation of the nation. At the same time there should be no room for the primitive elements of culture, "false pride"and other"schisms". Saying this, De Luca implicitly refers to the wide associations of Scotland's culture with tartan, kilt or haggis. In a way this poem can be regarded as a reaction to Tartanry1, which has been overemphasized in recent years for the sake of tourism. The real culture that should bind people includes the language, literature and art (a culture that imparts, inspires, demands a rare devotion) which were ruthlessly overshadowed by the dominance of the English culture. Thus, among other things, this poem is an appeal for the "reimagination" of Scotland and its authentic culture and freeing the country from the imposed stereotypes. In this respect, the poem serves a noble aim to urge the people of Scotland to find the true value and meaning of being Scottish no matter outside or within the UK.

Indyref in its resonance and the atmosphere created in the country because of the division into "Yes" and "No" parties can be explained in terms of Caledonian Antisyzygy, a term coined by G. Gregory Smith (Smith 1919), which stresses the "idea of dueling polarities that come together to make up Scotland, a definition which is believed to adequately describe the divided nation that Scotland represents. Throughout the history under the rule of England the Scots fought for preserving their identity which left them with a split identity. The story seems to never end and after hundreds of years of Union and Struggle the nation is again in turmoil and divided into two camps. Dwelling upon this issue, Brian Groom in his article Scotland, Forever in Two Minds published in Financial Times (Groom 2014) comes to the conclusion that "The Scottish people are very against the English, though the majority 
prefer to allow them to dictate and govern for Scotland; this was proven in the 2014 Referendum that was not passed. 55\% of people who voted did not want to break from England and become independent, but $45 \%$ did. The divide is nearly half and half, another way of showing that Scotland is still just as divided today as it was three hundred years ago".

The idea of dueling is central in Irfan Merchant's poem Storm, or the Undecideds (2014). Built on antithesis, the poem brings forth this very image of Scotland "forever in two minds". The poem images the people on the deck of a ship, where some are sunbathing on the deck, while others huddle inside keeping warm, some wonder who will first walk the plank, others argue about who should be the last. People on the deck are also divided into two sides each with its expectations and visions of the future. The gap between the two sides and the estrangement of the two camps from each other is so deep that they have lost common understanding even about most ordinary things /Some see an iceberg on the horizon; others believe it's the light /.

The poem questions the problem of trust - trust in the political power who has initiated the 2014 Referendum:

Though all disagree, each is convinced, as the waves continue to roll, our ship would surely be safely in harbour if they were in control.

There are those who have said the Captain is dead and have looted the ship's supplies, launched the lifeboats to make their escape but all of them capsized.

Some still have faith in the Captain's hands, steady as she goes; they're drinking martinis in the cocktail lounge, not minding which way the wind blows. 
The Scottish National Party (SNP), which stormed to victory at the Scottish Parliament election in May 2011, announced that the majority win is "a victory for a society and a nation". During the address in Edinburgh after the win, SNP First Minister vowed to govern for all of the ambitions of Scotland and for all the people who imagine that the nation can live in a better land. "This party, the Scottish party, the national party, carries your hope. We shall carry it carefully and make the nation proud." (https://www.bbc.com/news/ukscotland-scotland-politics-19907675).

Despite the controversies between the camps, the people on the ship believe that it will safely reach the harbor, on the condition that it is in control (Our ship would surely be safely in harbor if they were in control). So the captain has the serious task of guiding the people throughout the process. SNP which reflects the hope of the nation promised to "carry it carefully", but should people have trust in this promise? In 1707 the Kingdom of England and the Kingdom of Scotland united into one Kingdom, each side having its perspective on the necessity of the Union, but neither the people of England nor those of Scotland were happy of the fact. The poem sounds a warning against the repetition of the past when personal and financial interest finally took over the popular interests.

The motives of Scottish Independence Referendum were multilayered ranging from economic to social and political ones including issues of democracy and inequality. All of the motives combined together prove that the most significant motive for Independence remains the issue of National Identity. The Scottish sense of national identity has significantly contributed to the development of the debate over independence. For the people of Scotland Independence means fairness, prosperity and democracy, values that Scotland has been deprived of because of the UK government's failure to create conditions for Scotland's sustainable development. This feeling of unfairness and the inability of the country to make its own decisions gave rise to a huge number of "anger" poems which respond vehemently to the problems facing the nation. Among the writers and artists involved in the "Yes"campaign for the Scottish Independence Referendum, was Alan Bissett, a famous author and 
performer, who stands out for his radical "Yes" vote. His poem Vote Britain (2012) sounds an appeal for all the undecided ones. The heavy ironic tone and anger are the tools to make people listen and wake up to face the reality. The poem abounds in Anti-English sentiments and expressions of anger toward and the deep contempt for the Empire (Vote with your love for the Queen who nurtured you, cradle to grave, Who protects you and cares, her most darling subjects, to whom you gave the glens she adores to roam freely through, the stags her children so dearly enjoy killing), the past and current policy and the disastrous Westminster decisions (Vote for the Highland Clearances. Baaaaaaaaa; Vote for nuclear submarines in your water; Vote for oil revenue, which we ensure flows directly from us into you. Vote for our proud shared history of enslaving other nations and stealing their natural resources), the UK media (Vote for our voices dominating your media, but in no way telling you what to think. Vote for Scotland being referred to as a 'region', like, say, Yorkshire? Or East Anglia?), etc. Between the lines we hear the voice of compassion for the nation, who has been rejected the freedom of expressing its attitudes, because the media in the UK has always worked against the Scots, labeling them as anti-English, parochial, and Scotland - as "region". The message the poem sought to get across to the people was that the decisions about Scotland should be taken only by the people of Scotland and this is the only way to guarantee welfare for the people of Scotland.

A conspicuous feature of anger poems undoubtedly remains the use of the Scots Language and Gaelic intermingled with numerous references to truly Scottish realia. The closer look at the poems advocating "Yes" vote shows the validity of Benedict Anderson's postulate that "nationalism and language are closely related to each other"(Anderson 1991). The use of Scots expresses the existence of a separate nation and country. In Vote Britain the choice of the language units 'glens, eh? wee, deep fried mars bar, whisky, mooth' and references to 'Jock, Braveheart, Robert Burns, Kircudbright, etc.' is a deliberate one aimed at equalizing the status of Scots /considered subordinate/with that of English, while the reference to the Scottish realia emphasizes the idea of Scotland's unshared values with the rest of the UK. 


\section{Politics and Poetic Discourse in the Digital Space}

The latest political changes have coincided with the increasing popularity of social media, as a result of which published poetry has ceased to be the monopoly of professional authors. Professional poets, however, also use every opportunity to go digital and reach the average reader through interviews or exclusively published pieces, thus setting the mood and the trend of what to write and how to write.

Carol Ann Duffy, whose duties as the Poet Laureate make her respond to current issues, willingly uses electronic media opportunities to promote her new works. The poem Campaign (2017) tackling the general election of 2016 was published not only in the paper version of The Guardian, but also on their Web page, thus reaching a much larger audience.

The poem savages the incumbent Prime Minister, Theresa May. The criticism of Brexit is apparent: her mouth a ballot-box that bit the hand that fed, referring to the growing financial dependence of the UK from the EU. Theresa May is portrayed as a lying merciless politician.

\section{... her body was a question-mark querying her lies; her mouth a ballot-box that bit the hand that fed. \\ Her eyes? They swivelled for a jackpot win. Her heart was a stolen purse; \\ her rhetoric an empty vicarage, the windows smashed.}

(Almost the same vocabulary and imagery are used by Hilary Mantel to describe the first female PM Margaret Thatcher in the short story The Assassination of Margaret Thatcher. the same image of the eye, cruelty, and power-hunger). The poem describes the furious young generation that "ran towards her through the fields of wheat". However, it is difficult to say whether the author intended this as an indirect reference to The Catcher in the Rye, either contrasting the generation of Holden Caulfield with contemporary young people who are politically more active and do not mind growing up, or 
comparing British and American attitudes to the role of young people in politics. Duffy describes Theresa May as absolute evil and attributes devilish features to her, e.g. stiletto heels growing from her feet. It is also notable that in the poem May is compared to a male.

Theresa May is not the only object of Duffy's bitter criticism. In Sincerity, her last collection written in the capacity of the Poet Laureate (Duffy remains such until 2019) to be published in November 2018, the poet compares "the two evils: Brexit and Trump" and says these two phenomena inspired her latest political poetry. It seems, though, that the title, Sincerity, can be easily replaced with the word "obscenity". Duffy's rejection of Donald Trump manifests itself through extremely offensive language: news-maggot, twitter-rat and Mandrake Mymmerkin (an allusion to William Dunbar's poem The Flyting of Dunbar and Kennedy) are to name but a few (Youngs 2018). In a way, Duffy follows the pattern of Persian poets of old days who exercised in the art of insult. However, Duffy's current poetry is far from Persian poetic duels where both opponents had their turn to speak. Understandable though Duffy's feelings are, these poems lack elegance and balance of her previous works (e.g. on the Independence Referendum in Scotland) or the works of other poets who write on the same issues. In the poem $E_{X}$-Ministers the poet compares the ex-Cabinet with a force, driving the nation to "go over the white cliffs of Dover", like lemmings.

Carol Ann Duffy may rival another Poet Laureate, Philip Larkin, once called "The Most Politically Incorrect Poet". Duffy tries to be politically correct to the maximum but tends to forget about the voting majority who made Brexit and Theresa May's victory or Trump's victory possible, i.e. more than a half of the population in the UK/USA respectively. (The peculiarity of the US election system is widely known, but we may be safe to assume that if Trump is now President, there must be supporters, too).

Duffy's previous works, regardless of her feelings, are considerably more dynamic and unbiased from political and poetic points of view. The Scottish independence referendum was presented in the poem September 2014 with elegance and style. Admitting that both a thistle and a rose can draw blood, the 
poet draws parallels between England and Scotland, comparing their poetic legacy (Keats and Burns). She addresses the people over the Scottish Borders, i.e. the English, as cousins, sisters and brothers and praises England as the bold and brave country.

\author{
Aye, here's to you, \\ cousins, sisters, brothers, \\ in your brave, bold, brilliant land: \\ the thistle jags our hearts, \\ take these roses
}

from our bloodied hands. (Duffy 2014).

The poet admits there is blood on the hands of both nations, but offers the gift of mutual respect and love.

The insult trend can be clearly seen in the poetry published online by amateur authors, encouraged by a variety of literary projects. Many authors cannot avoid direct insults and bursts of negativity. By analysing Brexit-related poems on Twitter, Facebook and poetry platforms, it is easy to see that the number of likes is proportionate to the use of strong language despite the fact that such poetry is of rather low quality and serves as a vent for emotions. The poem below is an example of such poetry (https://hellopoetry.com/tag/brexit), although we have chosen an example without direct insults (the spelling and punctuation are as in the original).

\title{
Lets not exit Brexit
}

Twenty third June twenty sixteen

The biggest vote we'd ever seen

Results are in and Brexit win

and many say it's such a sin

Those who voted not to leave

This news they just could not believe. 
It would be interesting to analyse why it is poetry that people resort to in the attempt to express their feelings about Brexit. In comparison, in Russianlanguage posts concerning political issues in both Russia and abroad there are very few comments, if any, written as poems, while prosaic texts clearly dominate. Now we may only assume that while having a desire to share thoughts and ideas, people avoid writing long comments in order not to sink into frustration. A limited space of a tweet of an Instapoem forces them to choose the shortest possible way of expression, and poetry suits this purpose perfectly.

Paradoxically, Brexiteers seem to be under-represented in social media poetry projects. The British internet-community almost unanimously calls for another referendum. Recent anti-Brexit protests in London have shown that most Brexit opponents come from London, Northern Ireland or Scotland. This is explained by the unresolved issue of the Irish Border and the status of the UK nationals living in continental Europe. The North and the agricultural regions, hit hardest by the EU regulations, are mostly Brexiteers. Having to cope with everyday survival, people may not have time or desire to write about it. However, they may avoid praising Brexit because, positive or negative, it will be a serious challenge for the whole country. The few optimistic amateur poems on Brexit lack literary merit and are rather poorly rhymed couplets than poetry.

Here is another example, this time of pro-Brexit poetry submitted to the pre-Brexit competition (https://www.theneweuropean.co.uk/top-stories/antibrexit-poetry-in-response-to-telegraph-editor-1-5500142).

"Red for the poppy, brave and bold

"Blue for the passport, so proud to hold

"White for the flag we wave as we exit

"Thank God for Mrs May and our glorious Brexit.

However, it cannot be denied that the political changes in the UK triggered an unprecedented wave of creativity and self-expression. It would be wrong to think, however, that people who do not use the Internet for these purposes are 
excluded from the general fad to compose politically charged lines. Poet Chris Jelley, together with the Lynmouth Pavillion project, installed six poetry boxes across Exmoor to find more than 6,000 poems written not only on eternal topics of love, marriage and sadness, but also on pro- and anti-Brexit ideas.

\section{Conclusion}

Poetry has always been a highly controversial form of art. On the one hand, it aims to appeal to the reader's aesthetic feelings. On the other hand, poets have traditionally used their skill to respond to reality, events and current situations regardless of the scale of those. That is why political poetry is by no means a recent phenomenon. Although studies of history are based on documents rather than poetic interpretations, literary works have become an excellent tool to assist in gauging the mood of a nation in the times of change.

The recent political and social life in Britain has been marked by a variety of turning points, difficult choices and uncertainty. The Scottish independence referendum, Brexit and related issues, such as the Irish border, are changing the political map of Europe. TV and the Internet give a thorough (sometimes too thorough) explanation of the current processes and procedures. It may seem that there is no room for subjective emotions and personal feelings in the highly documented world. However, strangely enough, poetry has found its place in this politicized atmosphere: it is turning into voxpopuli, involving common people into discussion alongside with professional authors. The quality of some poetic works may be questionable, but we may regard it as a positive sign that people prefer ballot-boxes and poetic debates to weapons.

\section{Notes:}

1. According to Collins Dictionary Tartanry is the excessive use of tartan and other Scottish imagery to produce a distorted sentimental view of Scotland and its history (https://www.collinsdictionary.com/dictionary/english/ tartanry). The word includes all material stereotypes and symbols that characterize Scotland as a country and the Scottish as a nation. 
2. Scottish National Identity is a term referring to the sense of national identity, as embodied in the shared and characteristic culture, languages and traditions of the Scottish people (https://en.wikipedia.org/wiki/ Scottish_national_identity). National Identity is the main argument of the Scottish people who are in favor of independence, claim that the Scottish have a distinct identity and should have the right for "home rule".

\section{References:}

1. Anderson, B. (1991) Imagined Communities: Reflections on the Origins and Spread of Nationalism. $2^{\text {nd }}$ edition, London.

2. Groomin, B. (2014) Scotland, Forever in Two Minds. Financial Times. FT.3 Feb. 2014. Available at: <https://www.ft.com/content/553411c4-8aae-11e39465-00144feab7de> [Accessed September 2018]

3. Smith, G.G. (1919) Scottish Literature, Character and Influence. London: Macmillan Publishing, pp. 4-20.

4. Timeline: Scottish Independence Referendum (2011) Available at: <https://www.bbc.com/news/uk-scotland-scotland-politics-19907675> [Accessed September 2018].

5. Youngs, I. (2018) Poet laureate Carol Ann Duffy's parting shot at Donald Trump and Brexit.Available at: <https://www.bbc.com/news/ entertainment-arts-45837842> [Accessed October 2018].

6. Wallace, G. (2002) New Currency Or Old? - 'The Coin', By Edwin Morgan. Available at: <https://www.thebottleimp.org.uk/2007/11/new-currency-orold-the-coin-by-edwin-morgan/> [Accessed December 2018].

\section{Sources of Data:}

1. Bissett, A. (2012) Vote Britain. Available at: <https://alanbissett.com/ 2012/01/13/my-contribution-to-the-debate-on-scottish-independence/> [Accessed September 2018].

2. De Luca, C. (2014) The Morning After. Available at: <https://www.scotti shpoetrylibrary.org.uk/poem/morning-after $>$. [Accessed September 2018]. 
3. Duffy, C.A. (2017) Campaign - a poem by Carol Ann Duffy exclusively for the Guardian. Available at <https://www.theguardian.com/books/2017/jun /10/cam paign-a-poem-by-carol-ann-duffy-exclusively-for-the-guardian> [Accessed September 2018].

4. Duffy, C.A. (2014) September 2014. Available at: <https://www.theguar dian.com/books/2014/sep/23/carol-ann-duffy-poem-scottish-independen ce-referendum-september-2014> [Accessed 29 September 2018].

5. Lets not Exit Brexit. Available at: <https://hellopoetry.com/search/poems/? $\mathrm{q}=$ lets+not+exit $>$ [Accessed October 2018].

6. McDiarmid, H. (1926) The Drunk Man Looks at the Thistle. Available at: <https://www.poetryfoundation.org/poems/46796/a-drunk-man-looks-atthe-thistle> [Accessed October 2018].

7. Merchant, I. (2014) Storm. Available at: <https://www.scottishpoetryli brary.org.uk/poem/storm/> [Accessed September 2018].

8. Morgan, E. (2004) For the Opening of the Scottish Parliament 9 October 2004. Available at: http://www.scottishpoetrylibrary.org.uk/poetry/poems /opening-scottish-parliament-9-october-2004> [Accessed September 2018].

9. Politics: Culture and the 2014 Scottish Independence Referendum, One Year On.' Available at: <https://www.youtube.com/watch?v=rjoXXEc7 qo8> [Accessed October 2018].

10. The Telegraph Asks for Brexit Poems and It All Goes Wrong. Available at: $<$ https://www.theneweuropean.co.uk/top-stories/anti-brexit-poetry-inresponse-to-telegraph-editor-1-5500142> [Accessed October 2018].

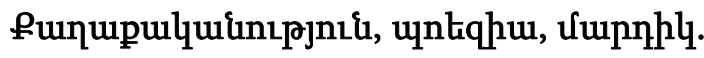

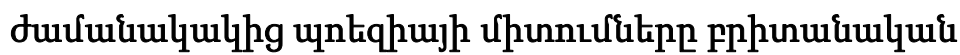 qpulqui juin2ưunnư}





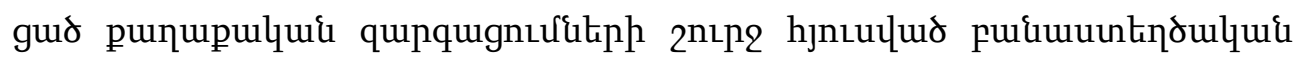

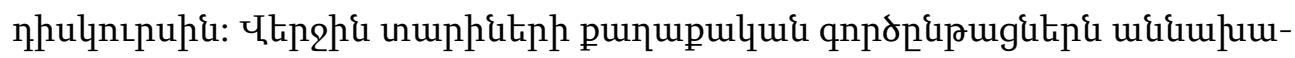




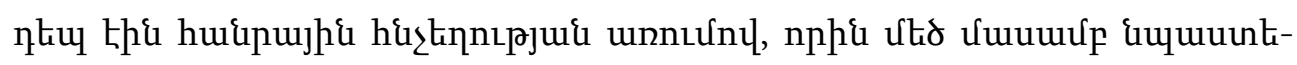

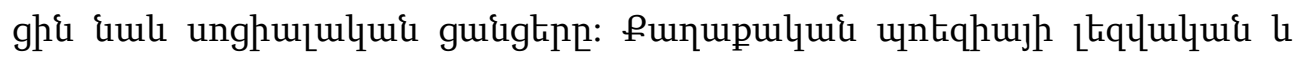

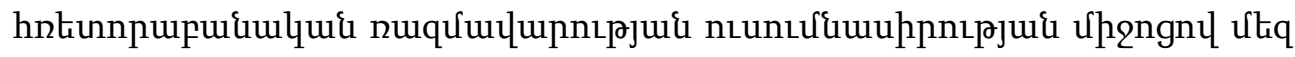

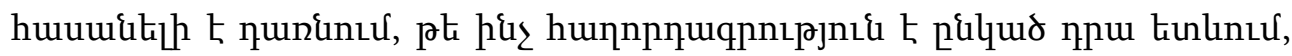



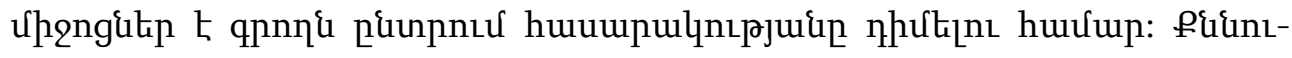

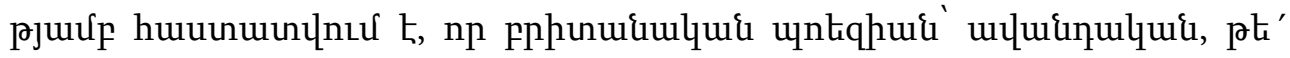



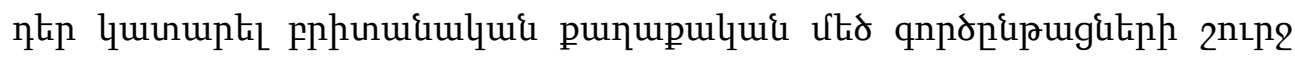



Received by the Editorial Board 11.02.2019

Recommended for publication by the reviewers 01.04.2019

Accepted for print 22.04.2019 